\title{
2. The Battle for Hearts and Minds
}

\author{
Carol Johnson
}

\section{Winning hearts}

It is increasingly recognised that emotion plays a very important role in politics and at election time in particular. Emotion (for example, in terms of feeling fear, anxiety, hope, empathy, pride) is central to election policy debates. Politicians evoke emotions such as fear and anxiety to encourage opposition to government debt or to garner support for tougher border security measures. They evoke feelings of hope to foster support for the vision of the future enshrined in party policies. They encourage feelings of pride to support arguments based on national identity. They encourage feelings of empathy for some groups that are seen as legitimate and deny empathy to those who aren't, with implications ranging from policies on asylum seekers and welfare recipients to policies supporting 'mainstream' voters (see further Johnson 2005 and 2010).

International research has emphasised the important role played by emotion in political advertising (Brader 2006) and election campaigning more broadly (Westen 2007). Further research demonstrates that emotion plays a key role in encouraging the electorate to engage with political issues and in influencing electors' decisions to change political views and allegiances (Marcus et al. 2000; Marcus 2002; Neuman et al. 2007; Brader 2006). Westen (2007: 125) goes so far as to claim that 'the data ... are crystal clear: people vote for the candidate who elicits the right feelings, not the candidate who presents the best arguments'. Redlawsk (2006: 10) draws on recent neurophysiological research to come to a slightly more balanced approach — albeit one that still emphasises the importance of emotion - arguing that politics is 'about feeling every bit as much as it is about thinking.' Consequently, feeling is the key aspect of emotion on which this chapter will focus.

It should therefore not surprise us that appeals to emotion were regularly used by politicians from both major parties during the 2013 Australian election campaign, although obviously this is only one of many aspects of campaign strategy that will be discussed. Nonetheless, it will be argued here that the use of emotion was highly significant because it was so closely tied to the battle for minds. In particular, the battle of ideas and its underlying ideological components tended not to be fully articulated in the 2013 election campaign (see the following chapter by Strangio and Walter). However, an analysis of 
election policy discourse reveals that ideology was still playing a significant, if somewhat subterranean, role. It was simply that, rather than explicitly spelling out opposing views in depth, politicians often attempted to evoke differing ideological positions by mobilising differing fear campaigns and differing forms of the politics of reassurance. ${ }^{1}$ In short, party-specific political positions were evoked via party-specific forms of emotional frameworks that closely intersected with forms of ideology (see Johnson 2010).

Tony Abbott had identified what were to be key features of the emotional framework underlying his 2013 campaign in a policy speech he gave a year earlier:

John Howard was onto something when he said that he wanted Australians to feel more 'relaxed and comfortable' about our country. People naturally seek the reassurance that their job is safe, their doctor is available, their children go to a good school, their neighbourhood is friendly, and their country is secure ... These days, there's an even deeper sense of public unease about where we're headed, only the uncertainty is more economic than cultural (Abbott 2012).

Abbott's campaign to win hearts by using emotion therefore centred around two main strategies. The first was to encourage voters to feel afraid and anxious by emphasising the Coalition's argument that Labor posed a threat to the economy (e.g. via government debt) and to border security (failing to 'stop the boats'). The second strategy was to neutralise Labor fear campaigns against the Coalition, based on arguments that the Coalition would make substantial budget cuts, by encouraging voters to feel reassured that a Coalition Government would continue to provide jobs, good education and health services.

There was far less focus than during previous Howard campaigns on evoking cultural insecurities and anxieties, for example, in terms of 'culture war' arguments about national identity or arguing that politically correct special interests were stealing government resources from mainstream Australians (see further Johnson 2007: 39-73). Nevertheless there were residual hints of such culture war arguments, such as comments Christopher Pyne (cited in Owen 2013) made about alleged biases in the national school curriculum. Abbott (2013b) also accused Labor of encouraging division on the basis of factors such as gender and class, thereby downplaying forms of social inequality while also trying to counter Labor critiques of Abbott's conservative position on gender issues. However, the Abbott campaign mainly focused on reworking two other

1 Fear campaigns are being dealt with as a political campaigning strategy in this chapter and are analysed accordingly. An assessment of the legitimacy or otherwise of the fears and anxieties being evoked by politicians is beyond its scope. This chapter also focuses on analysing political discourse but it should be noted that the politics of emotion is also evoked via images and other forms of non-verbal communication. 
old Howard election strategies: attempting to motivate a fear of Labor economic incompetence and government debt, and a fear of asylum seekers. The ongoing impact of the global financial crisis (GFC), including the after-effects of Rudd stimulus package expenditure combined with drastically falling government revenues, provided particularly fertile ground for the Liberals to highlight issues of government debt.

In addition, Abbott had spent much of his period as Opposition Leader encouraging feelings of insecurity by suggesting that the minority Labor Government was both dysfunctional and likely to fall at any time - although it actually served a full term and passed over 500 pieces of legislation. Nonetheless, Labor's leadership instability, publicly expressed disunity and differences of opinion, combined with scandals over Peter Slipper and Craig Thomson, were fertile ground for the Opposition Leader to exploit. During the campaign itself, Abbott (2013b) built on his previous arguments, suggesting that the deposing of Julia Gillard and the reinstalling of Kevin Rudd were further evidence that it was 'faceless men' rather than the people who were running the country, and stated that a third of cabinet ministers had resigned. He claimed that there was a 'rent in our polity' and 'a political crisis' (Abbott 2013b). The consequence was that 'an exasperated people are looking for stability and certainty and the only place they will find that stability and that certainty is with the Liberal National Coalition' (Abbott 2013b). Or, as he spelled out in more detail elsewhere:

There is only one way that Australians can be sure to leave the chaos, the division, the failures, the bloodletting and the politics behind, for good, and that is to change the government. Only the coalition can be trusted when we say: there will be no deals with the Greens, no deals with flaky independents, no deals whatsoever ... Above all we will return stable, certain, competent government so all Australians can again plan their futures with confidence (Abbott 2013d).

Such statements provide classic examples of Abbott's key strategy of first encouraging feelings of anxiety then providing and encouraging feelings of reassurance. The Liberals particularly emphasised the importance of feelings of economic reassurance and security. Abbott (2013b) stated that voters should ask themselves 'Who can make your future more secure? Who can make your life better? Who can ease your cost-of-living pressures and who can make your job more safe?' The answer was the Coalition, since only a new government could 'restore the hope, reward and opportunity that should be your birthright' (Abbott 2013a). As was the case previously with Howard, the Liberals were encouraging a feeling of nostalgia for a past golden age (see further Johnson 2007: 40-50). In Howard's (2006) case, the nostalgia was for the values of 'old Australia'. However, in 2013, the Liberals were not only evoking the certainties of the distant past - they were also claiming that Australia could return to (what 
they depicted as) the more recent certainties of the Howard period, by leaving behind the Rudd period in which Australia was governed by 'captain chaos' (Liberal Party of Australia 2013). Mobilising nostalgia fitted particularly well with the politics of reassurance. The implication was that Labor had robbed Australians of feelings of security, certainty and pride in their national identity, while the Liberals were depicted as the source of feelings of hope.

At the same time Abbott set out to reassure those who might have been impacted by Labor scare campaigns by suggesting that a Coalition Government would benefit all Australians. There was no re-stating of earlier comments by Joe Hockey (2012) that suggested there would need to be massive cuts to welfare and entitlements as Australia competed with Asian neighbours who spent a far smaller proportion of GDP on welfare and other benefits. Rather, Abbott (2013a) claimed: 'We must be a country that rewards people for having a gobut we must never leave anyone behind'. He reassured workers that 'your pay and conditions will be safe under a Coalition Government and that as far as is humanly possible we want your jobs to be secure' (Abbott 2013c). He affirmed that Australia was 'an immigrant nation' and that the opportunities Australia offered to newcomers were what made Australia 'a beacon of hope and optimism right around the world' (Abbott 2013b).

In evoking feelings of protection, Abbott drew on a particular form of fatherly protective masculinity (see further Johnson 2013), in which male heads of household look after their families. As Tony Abbott's daughter Frances stated at the Liberal Party campaign launch, after listing the support Abbott had given his daughters: 'My Dad looks out for everyone and I know he will look out for you' (cited in Nine MSN 2013). Abbott's version of protective masculinity was further strengthened by his hyper-masculine image of surf lifesaver and volunteer firefighter. As Sawer and McLaren's chapter points out, Abbott also made considerable efforts to try to reassure female voters that he wasn't too threatening or aggressively masculine, in the aftermath of Gillard's accusations that he was sexist and a misogynist. Meanwhile, his loving support for his lesbian sister, Christine, was used as evidence that he wasn't intolerant of gays and lesbians (60 Minutes 2013), while still using his opposition to same-sex marriage to reassure social conservatives who were anxious about the pace of social change.

In short, Abbott's overall strategy was to first evoke fear and anxiety and then to be the person who offered reassurance, attempting to neutralise Labor's scare campaign in the process. In Abbott's (2013a) words:

I will spend the next two weeks reassuring people that there is a better way while Mr Rudd will spend the next two weeks trying to scare you about what might happen if he doesn't keep his job. 
Abbott claimed during one of the leadership debates that as a result Rudd had no vision for Australia: 'If all you've got is a scare, you've got no vision for the future' (Abbott and Rudd 2013b). By contrast, the Liberal campaign focused on suggesting that they had a positive vision of, and plan for, the direction Australia should take (Loughnane 2013).

Both Gillard and Rudd faced dilemmas in attempting to counter Abbott's politics of emotion. Gillard was well aware of the ways in which Abbott was attempting to mobilise fear and anxiety. She understood that 'Australians have been screamed at now by the Opposition for more than a year. They've been told that they need to be very afraid ... we all know a good fear campaign when we see one' (Gillard 2012). Such strategies were even more effective, in her view, because 'Australians ... are still feeling anxious from the days of the Global Financial Crisis' (Gillard 2012). She appeared to have hoped that time, and Labor's compensation packages, would prove Abbott's scare campaign on the carbon price/tax to be unfounded (Shanahan 2011). However, Abbott (2011) had retaliated by suggesting - as part of the politics of reassurance - that the carbon tax was an issue of 'trust', and only the Liberals could be trusted to keep their promises. Gillard hoped to succeed in making voters anxious about Abbott by arguing that he was negative, aggressive and dangerously sexist. However, as we have seen, Abbott (2013b) responded by conveying a family-friendly image and arguing that Labor was encouraging division on the basis of gender. Gillard attempted her own politics of reassurance by stressing that Labor governments had a long history of introducing measures that addressed peoples' fears of facing hard times, via measures such as aged pensions, Medicare and now the disability insurance scheme (Gillard cited in O'Reilly 2012). However, Abbott partly undermined this strategy by embracing the disability insurance scheme as a bipartisan policy (see further the contribution by Gray, Manwaring and Orchard in Chapter 21).

Labor was also somewhat hamstrung in attempting to counter Abbott in that Rudd initially seemed to avoid running on Labor's policy record during the Gillard years. However, Labor began to emphasise that record again towards the end of the campaign. Despite his own promise to run a positive agenda, Rudd spent a great deal of the lead-up to the campaign trying to neutralise what he argued were Abbott's scare campaigns:

Mr Abbott is a formidable politician - he is the nation's most formidable exponent of negative politics, and negative politics above all designed to induce feelings of worry, anxiety and fear in the community. He and the Liberal Party have concluded that fear is a far better political bet than engaging on a debate on the facts (Rudd 2013a). 
For example, Rudd argued that there was not a 'budget emergency' over debt as Tony Abbott had claimed in his 2013 Budget Reply Speech (Parliament of Australia 2013). Rudd (2013a) provided figures to demonstrate that Australia's economic performance actually compared very favourably with that of other western economies and that Australia's level of government debt was also low by comparison. Rudd (2013a) argued that Abbott's strategy was to 'Run away from the facts. But keep pumping out the fear'.

Nonetheless, Rudd had his own version of a fear campaign, in this case regarding the cuts which Labor argued that an Abbott Government would introduce. He argued that Abbott was doing everything he could to avoid proper financial scrutiny because if 'you the Australian people knew the dimensions of what he and his government are planning by way of cuts ... you would not vote for him' (Rudd 2013c). Rudd's (2013c) message to the Australian people was therefore a simple one:

if you are in doubt after all this evasion on how Mr Abbott's massive cuts would hurt your jobs, your schools and your hospitals and the economy in this most fragile of global economic times, don't vote for him.

By contrast, Rudd (2013c) argued that his own key mission was to ensure that voters' jobs were secure. With that in mind, Rudd (2013a) argued that Labor had steered Australia through the GFC and only Labor could be trusted to steer Australia through the end of the China-led resources boom and to build a diverse, 21 st century economy that was not overly dependent on mining and had good infrastructure, including high speed internet. It would be an Australia where there was a 'fair go for all', where people could access good health care and a good education regardless of income, and there would be no discrimination on the basis of gender, race or sexuality (Rudd 2013b). It was an argument, however, that Rudd did not win.

\section{Winning minds}

As other chapters will make clear, election policies and campaigns are influenced by a range of factors, including purely pragmatic - not to say opportunistic ones that can also be shaped by a range of methods designed to ascertain public opinion (see e.g. Chapter 1 by Rayner and Wanna and Chapter 7 by Reece). The Coalition also made strategic decisions in an attempt to neutralise some key policy differences in areas such as education and health (see Chapter 21 by Gray, Manwaring and Orchard). However, it would be unfortunate to lose sight of the fact that there were also underlying ideological differences between the Liberal and Labor parties. This chapter therefore takes issue with those who argue that 
there has been a fundamental convergence between Labor and the Liberals that has dissolved any meaningful ideological differences between the major parties. ${ }^{2}$ Rather, as suggested previously, this chapter will argue that ideological differences frequently underlay the different emotional frameworks that were being evoked. In particular, ideological differences influenced what voters were encouraged to feel fear and anxiety about, as well as the forms of the politics of reassurance that were offered.

Ideology is often implicated in the politics of emotion (see Johnson 2010). So, for example, neo-liberal political ideology is often associated with encouraging fear of debt and big, intrusive government, while feelings of hope are seen to lie in encouraging individual initiative and self-reliance in a market context. By contrast, social democratic ideology is often associated with encouraging feelings of security via assurances that government will promise a safety net in times of market failure (Johnson 2012). Similarly conservative social and political values can be articulated through fear of the 'other', for example, asylum seekers - a fear which Labor chose to combat in the 2013 election via the harsh measures of the 'PNG solution' (see Chapter 19 by Jupp), rather than by attempting to diffuse it and encourage empathy for those fleeing persecution. There were therefore strong ideological underpinnings to the forms of the politics of emotion that have been discussed previously, that are intertwined with both the politics of fear and the politics of reassurance.

Kevin Rudd alluded to such ideological differences between Labor and the Liberals during one of the leaders' debates. He characterised the difference as being between a nation-building agenda and one focused on budget cuts and claimed that:

This debate is one which has a long resonance ... in the competing traditions of Australian political history. We're not simply looking at an isolated series of events today. They are part and parcel of two competing political ideas on the role of government in both the economy and society ... (Rudd 2013c).

He also argued that making savage cuts was consistent with previous Coalition Government actions, according to the 'consistent Conservative script', given the commission of audit and subsequent major budget cuts established by the Howard Government (Rudd 2013c). Rudd (Abbott and Rudd 2013c) explicitly identified Abbott's position as 'ideological', arguing that massive cuts could

2 For an excellent account, and independent analysis, of views on the ideological convergence of major parties see Goot (2004). For an analysis of the ongoing influence of ideology in Australian politics see Edwards (2013). 
drive the Australian economy into recession and that 'I understand the ideology, I understand the policy but it is the wrong policy and it's doubly wrong at this time' [emphasis added].

The ideological differences that underlay Rudd and Abbott's positions at the 2013 election had emerged much more explicitly, in 2009, in a debate over the best way to respond to the GFC. As is well known, Kevin Rudd (and Wayne Swan) had both argued for a Keynesian-influenced response to the GFC, using a substantial government stimulus package (Rudd 2009; Taylor and Uren 2010). Furthermore, Rudd (2009) argued that the GFC had largely been caused by neo-liberal deregulation and made a Keynesian case for the need for ongoing government regulation and intervention in order to smooth out the cyclical downturns of capitalism. Rudd's arguments were quite consistent with previous critiques he had made of neo-liberal ideology (Rudd 2006a, 2006b and 2006c) although he had downplayed explicit statements of such positions during the 2007 election campaign.

Significantly, before he became Opposition Leader, Abbott (2009) had penned a stinging critique of Rudd's arguments regarding the nature of, and policy prescriptions for, the GFC, depicting Rudd as a 'misguided, would-be Messiah' who had 'confused a cyclical (if severe) downturn with a fundamental crisis of capitalism'. Abbott (2009) had been particularly critical of Rudd's arguments in support of social democratic government interventions in the economy, arguing that Rudd was putting forward 'socialist' arguments. Abbott (2009) went on to deny that neo-liberal ideology had shaped government policy in Australia, while suggesting that individuals and businesses generally made better decisions regarding their best interests than government could; that debtfuelled spending would exacerbate problems and that 'a permanent tax cut is more likely to encourage the initiative culture that will soonest restore strong economic growth', along with measures such as lower interest rates and cutting government regulation. In short, although he would deny the tag, Abbott was putting forward arguments that are commonly associated with neo-liberalism (see Harvey 2005; Crouch 2011).

By the 2013 campaign launch, Abbott's (2013a) ideological position was articulated less explicitly, but he did claim that under a Coalition Government 'each year, government will be a smaller percentage of our economy'. He also pledged to cut the carbon and mining taxes, as well as to cut red tape because:

We understand, deep in our DNA, that you can't have a strong society and strong communities without strong economies to sustain them and you can't have a strong economy without profitable private businesses. We know that a stronger economy is not about picking winners but about helping everyone to get ahead (Abbott 2013a). 
Parties these days rarely use the term 'ideology' about their own position, preferring to retain a negative, pejorative use of the term that can be used against their opponents, while their own position is depicted as being both pragmatic and the truth. However, terms such as 'DNA' (Abbott 2013a) or 'values' (see Rudd 2013b) are often used to refer to underlying ideological differences about, for example, the respective roles of government and the market, as the following passage from Abbott also makes clear:

This ... is the clearest choice in a generation and it is not just between two different teams and two different policies. It is not just between unity and stability on one side and division and dysfunction on the other. It is a choice about fundamental values. It is a choice about what we believe in as a people and as a nation. And I say to the Australian people the Labor Party right now is addicted to big government. They just can't help themselves. Here in the Coalition we believe in strong citizens, Labor is only interested in wealth redistribution. But we the people understand that you have got to create the wealth before you can distribute it. Labor obsesses about the state but we the people understand that it is in community that Australian people will be strong, and strong communities and strong individuals are what we need if the social fabric of this great nation is to improve in the months and years ahead (Abbott 2013b).

Abbott's position was consistent with many arguments that would have been put forward by the Howard Government (see Johnson 2007).

However, Rudd faced problems in articulating his position because of a widely acknowledged ideological crisis of social democracy at an international level (Lavelle 2008: 1; Nahles and Cruddas 2012: viii), which has also been noted in the Australian context by commentators as diverse as journalist and labour historian Troy Bramston (2011) and Liberal Party Federal Director Brian Loughnane (2013: $4,14)$. The crisis partly revolves around social democratic parties' attempts to address the relationship between government and market, following the partial embrace of a watered down form of neo-liberalism (in which the Australian and New Zealand labour parties were pioneers). That partial embrace of neoliberalism by Labor, especially from the Hawke and Keating period onwards (Lavelle 2005), made it harder for Swan and Rudd to argue for the re-embracing of some Keynesian strategies, particularly in regard to justifying running deficits and major government funding for nation-building projects. It also arguably made it harder to justify the mining tax (even if this was partly designed to redistribute mining profits to other sectors of the economy) and a carbon price (even if the longer-term pricing mechanism was to be a market-based emissions trading scheme). 
That partial embrace of neo-liberal ideology by previous Labor governments also had implications for the politics of emotion because it helped to reinforce a fear of government debt along with a fear of, and resentment towards, high taxing governments. The election outcome suggests that part of Rudd's problem in arguing his case was that Abbott's evoking of the fear of government debt and taxes appears to have been far more successful than Rudd's older social democratic strategy of attempting to make people feel secure and reassured by promising government intervention and benefits to ameliorate the impacts of dysfunctional markets. Abbott (admittedly greatly assisted by Labor's own major problems in regard to program delivery and catastrophic levels of internal disunity) seems to have succeeded in arguing that it was government rather than the market that was dysfunctional. The roles of ideology and emotion were therefore closely intertwined. In the process, Abbott won both the battle for hearts and the battle for minds.

\section{References}

60 Minutes. 2013. 'Tony Abbott'. Television broadcast, Nine Network, Sydney, 9 March. Presented by Liz Hayes. Viewed 15 December 2013: <sixtyminutes. ninemsn.com.au/article/8623144/tony-abbott>.

Abbott, Tony. 2009. 'Misguided, would-be messiah'. The Australian, 7 February, viewed 21 October 2013: <www.theaustralian.com.au/archive/business/ misguided-would-be-messiah/story-e6frgagx-1111118780014>.

Abbott, Tony. 2011. 'Tony Abbott's carbon tax address'. Transcript, SBS news online, 11 July, viewed 15 December 2013: <www.sbs.com.au/news/ article/2011/07/11/transcript-tony-abbotts-carbon-tax-address $>$.

Abbott, Tony. 2012. 'The Coalition's plans for stronger communities'. Tony Abbott, Federal Member for Warringah and Leader of the Opposition-News, 6 June, viewed 28 July 2012: <www.tonyabbott.com.au/LatestNews/ Speeches/tabid/88/articleType/ArticleView/articleId/8746/LandmarkSpeech--Address-to-the-Pratt-Foundation-Melbourne.asp $>$.

Abbott, Tony. 2013a. 'Address to the Federal Coalition Campaign Launch'. 25 August, viewed 14 October 2013: <www.liberal.org.au/latestnews/2013/08/25/tony-abbott-address-2013-federal-coalition-campaignlaunch>.

Abbott, Tony 2013b. 'Address to Victorian Federal campaign rally'. 2 July, viewed 14 October 2013: <www.liberal.org.au/latest-news/2013/07/02/tonyabbott-transcript-address-victorian-federal-campaign-rally-melbourne $>$. 
Abbott, Tony. 2013c. 'Address to workers, Narangba, Queensland'. 5 September, viewed 6 September 2013: <www.tonyabbott.com.au/LatestNews/Speeches/ tabid/88/articleType/ArticleView/articleId/9494/Address-to-workersNarangba-Queensland.aspx $>$.

Abbott, Tony, 2013d. 'At your service and offering a better way. A Statement by Tony Abbott'. The Australian, 5 August: 6.

Abbott, Tony and Rudd, Kevin. 2013a. 'Leaders' Debate'. National Press Club, 11 August, viewed 14 October 2013: <www.kevinrudd.org.au/latest3_110813>.

Abbott, Tony and Rudd, Kevin. 2013b. 'Peoples' Forum'. Brisbane Broncos Leagues Club, 21 August, viewed 14 October 2013: <www.kevinrudd.org. au/latestl_220813>.

Abbott, Tony and Rudd, Kevin. 2013c. 'People's Forum'. Rooty Hill RSL Club, 28 August, viewed 14 October 2013: <www.kevinrudd.org.au/latest3_280813>.

Bowen, Chris. 2013. 'Press Conference'. Canberra, 2 August, viewed 14 October 2013: <ministers.treasury.gov.au/DisplayDocs.aspx?doc=transcripts/2013/ 022.htm \&pageID $=004 \& \min =$ cebb $\&$ Year $=\&$ DocType $=>$.

Brader, Ted. 2006. Campaigning for Hearts and Minds: How Emotional Appeals in Political Ads Work. Chicago: University of Chicago Press.

Bramston, Troy. 2011. Looking for the Light on the Hill: Modern Labor's Challenges. Melbourne: Scribe.

Clarke, Simon et al. 2006. 'Moving Forward in the Study of Emotion'. In Simon Clarke et al. (eds), Emotion, Politics and Society, Basingstoke: Palgrave Macmillan.

Crouch, Colin. 2011. The Strange Non-Death of Neo-Liberalism. Cambridge: Polity Press.

Edwards, Lindy. 2013. The Passion of Politics: the Role of Ideology and Political Theory in Australia. Sydney: Allen \& Unwin.

Gillard, Julia. 2012. 'Address to Australian Council of Trade Unions Congress'. Sydney, 15 May, viewed 24 July 2012: <www.pm.gov.au/press-office/ address-australian-council-trade-unions-congress-sydney $>$.

Goot, Murray. 2004. 'Party convergence reconsidered'. Australian Journal of Political Science 39(1): 49-73.

Harvey, David. 2005. A Brief History of Neoliberalism. Oxford: Oxford University Press. 
Hoggett, Paul. 2009. Politics, Identity, and Emotion. Boulder: Paradigm.

Howard, John. 2006. 'A sense of balance: The Australian Achievement in 2006'. Address to the National Press Club, 25 January, viewed 18 December 2013: <pandora.nla.gov.au/pan/10052/20060321-0000/www.pm.gov.au/news/ speeches/speech1754.html $>$.

Johnson, Carol. 2005. 'Narratives of identity: Denying empathy in conservative discourses on race, class and sexuality'. Theory and Society 34(1): 37-61.

Johnson, Carol. 2007. Governing Change: From Keating to Howard. Revised edn. Perth: Network Books.

Johnson, Carol. 2010. 'The politics of affective citizenship: From Blair to Obama'. Citizenship Studies 14(5): 495-509.

Johnson, Carol. 2012. 'Social Democracy in Uncertain Global Times: Governing the Politics and Economics of Emotion'. Paper presented to the IPSA 22nd World Congress of Political Science, Madrid, July. Viewed 17 December 2013: < paperroom.ipsa.org/papers/paper_13011.pdf>.

Johnson, Carol. 2013. 'From Obama to Abbott: Gender Identity and the Politics of Emotion'. Australian Feminist Studies 28(75): 14-29.

Hockey, Joe. 2012. Lateline, Australian Broadcasting Corporation (ABC), Sydney, 18 April, viewed 27 October 2013: <www.abc.net.au/lateline/content/2012/ s3480665.htm>.

Lavelle, Ashley. 2005. 'Social Democrats and Neo-Liberalism: A Case Study of the Australian Labor Party'. Political Studies 53(4): 753-71.

Lavelle, Ashley. 2008. The Death of Social Democracy: Political Consequences in the 21st Century. Abingdon Oxon: Ashgate.

Liberal Party of Australia. 2013. Captain Chaos. Television advertisement, viewed 18 December 2013: <www.youtube.com/watch?v=I_W-Wf4hDOs>.

Loughnane, Brian. 2013. 'Address to the National Press Club'. Canberra, 23 October, viewed 26 October 2013: <lpaweb-static.s3.amazonaws. com/Brian \% 20Loughnane \% 20- \% 20National \% 20Press \% 20Club \% 20 Address \%20-\%2023\%200ctober \%202013.pdf>.

Marcus, George. 2002. The Sentimental Citizen: Emotion in Democratic Politics. Philadelphia: Pennsylvania University Press.

Marcus, George et al. 2000. Affective Intelligence and Political Judgment. Chicago: University of Chicago Press. 
Nahles, Andrea and Cruddas, Jon. 2012. 'Preface: Social Democracy in our Times'. In Henning Meyer and Jonathan Rutherford (eds), The Future of European Social Democracy: Building the Good Society, Basingstoke: Palgrave Macmillan.

Neuman, W Russell et al. 2007. The Affect Effect: Dynamics of Emotion in Political Thinking and Behavior. Chicago: University of Chicago Press.

Nine MSN. 2013. 'Softer Side of Abbott on Show'. Nine MSN News Online, viewed 25 August 2013: <news.ninemsn.com.au/national/2013/08/25/08/18/ abbott-to-float-tradie-loans-scheme $>$.

O'Reilly, Sue. 2012. 'Gillard's driving ambition to take the fear out of disability'. The Australian, 19-20 May, Inquirer: 12.

Owen, Michael. 2013. 'Christopher Pyne warns teachers against impeding reform'. The Australian, 4 September, viewed 25 October 2013: <www.theaustralian. com.au/national-affairs/election-2013/christopher-pyne-warns-teachersagainst-impeding-reform/story-fn9qr68y-1226710077163\#mm-premium>.

Parliament of Australia. 2013. House of Representatives Hansard. 16 May: 3571.

Redlawsk, David P (ed.). 2006. Feeling Politics: Emotion in Political Information Processing. New York: Palgrave Macmillan.

Rudd, Kevin. 2006a. 'Address to the Centre for Independent Studies'. 16 November, viewed 5 July 2007: <www.cis.org.au/events/policymakers/ krudd_lecture.pdf $>$.

Rudd, Kevin. 2006b. 'Child of Hayek'. The Australian, 20 December: 12.

Rudd, Kevin. 2006c. 'Howard's Brutopia: The Battle of Ideas in Australian Politics'. The Monthly, November: 46-50.

Rudd, Kevin. 2009. 'The Global Financial Crisis'. The Monthly, February: 20-8.

Rudd, Kevin. 2013a. 'The Australian Economy in Transition: Building a new National Competitiveness Agenda'. Canberra, 11 July, viewed 13 July 2013: $<$ www.pm.gov.au/press-office/address-national-press-club $>$.

Rudd, Kevin. 2013b. 'Building for Australia's future'. ALP campaign launch, Brisbane, 1 September, viewed 4 September 2013: <www.kevinrudd.org.au/ building_australia_s_future $>$.

Rudd, Kevin. 2013c. 'National Press Club Address'. Canberra, 5 September, viewed 9 September 2013: <www.kevinrudd.org.au/latest4_05091>. 
Shanahan, Dennis. 2011. 'Gillard's long game is a big gamble'. The Australian, 21 May, viewed 15 December 2013: <www.theaustralian.com.au/ national-affairs/opinion/gillards-long-game-is-a-big-gamble/storye6frgd0x-1226059944024>.

Sunrise. 2013. Television program, Channel 7, Sydney, 6 September. Interview with Kevin Rudd. Viewed 9 September 2013: <www.kevinrudd.org.au/ latest3_060913>.

Taylor, Lenore and Uren, David. 2010. Shitstorm: Inside Labor's Darkest Days. Melbourne: MUP.

Westen, Drew. 2007. The Political Brain: The Role of Emotion in Deciding the Fate of the Nation. New York: Public Affairs.

Young. Sally. 2004. The Persuaders: Inside the Hidden Machine of Political Advertising. Melbourne: Pluto Press. 
This text taken from Abbott's Gambit: The 2013 Australian Federal Election, edited by Carol Johnson and John Wanna, published 2015 by ANU Press, The Australian National University, Canberra, Australia. 